\title{
Financial performance of Slovak insurance companies. Covid-19 consequences
}

\author{
Janka Grofcikova ${ }^{1,}$, and Katarina Izakova ${ }^{1}$ \\ ${ }^{1}$ Faculty of Ecomonics Matej Bel University in Banska Bystrica, Department of Finance and \\ Accounting, Tajovskeho 10, 97590 Banska Bystrica, Slovakia
}

\begin{abstract}
Research background: Globalization trends are manifested at many levels as key phenomena of current business in the international environment. The development of international cooperation, interconnection of economies and emergence of multinational companies enable companies to increase their efficiency and performance, strengthen their position in the global market, which makes them resilient to global risks and increases investors' return on investment. Currently, the COVID-19 pandemic with its related side effects present significant global risks that have affected strong financial companies, insurance companies included. Risk-insuring insurers face several challenges in this regard in terms of fulfillment of contractual obligations towards clients on the one hand, and the need to ensure the required financial performance and return on invested resources for the owners on the other.

Purpose of the article: The aim of the paper is to identify and quantify the impact of the COVID-19 pandemic and related measures and consequences on the financial situation of insurance companies with the seat in Slovakia. Methods: The financial performance of insurance companies will be quantified for the years 2016-2020 through selected indicators of financial analysis that are used by Standard \& Poor's. Significance of differences will be detected through the Wilcoxon Two-Related-Samples Test. The sample of entities includes all insurance companies seated in Slovakia.

Findings \& Value added: The basic characteristics of the Slovak insurance market within the period 2019-2020 indicate a decrease in value of gross written premiums $(-2.47 \%)$, insurance claims and benefits $(-12.3 \%)$ and an increase of the reinsurer's share of written premiums $(2.17 \%)$ and of claims paid $(22.54 \%)$.
\end{abstract}

Keywords: financial performance; global risks; COVID-19 consequences; insurance companies; Slovakia

JEL Classification: F65; G22; M16; $M 19$

\footnotetext{
* Corresponding author: janka.grofcikova@umb.sk
} 


\section{Introduction}

Process of globalization under economic, social, political, sociological, technological, or ecological perspectives is an issue that has been discussed in both scientific and political environment for a long time. Nevertheless, a particular area concerning a field of financial globalization which is understood as a consequence of global integration of financial markets has been studied by Gaies et al., (2020), as well as Nasreen et al., (2020). In their studies, they focused on the role of financial globalization, institutions and economic growth in the context of financial sector development in European countries. Furthermore, Ulucak et al., (2020), found that financial globalization contributes to improving the level of environmental quality in emerging economies. The impact of globalization on insurance market activities in large emerging market economies has been examined by Olasehinde-Williams and Balcilar, (2020). They came to conclusions that all dimensions of globalization positively impact life and non-life insurance density. A scientific study of Leong et al. (2020) proves the fact that shadow insurance is a regulatory loophole that is exploited by certain insurance groups to increase risk exposure, which may potentially destabilise the financial system. With regard to this, there are rating agencies that objectively assess the financial situation of insurance companies. In a study by Huang and Shen (2021), they examine the (in) accuracy of the ratings of the Big three rating agencies, namely Standard and Poor's, Moody's, as well as Fitch. Eling and Jia (2019) examined the relationship between efficiency (with a data set of more than 5,000 insurance companies) and profitability. Basically, they found a significantly positive correlation between the efficiency measures and profitability measures. Ecer and Pamucar (2021) focus on identifying insurance companies' priority ranking during the COVID-19 outbreak through a multi-criteria performance evaluation methodology. In the face of corona virus disease 2019 (COVID-19), studies by Gu and Wang (2020) prove that it is necessary to further improve agricultural insurance, especially through providing insurance against market risks. Vera-Valdés (2021) show that shocks that originate in a pandemicassociated regime are more persistent than shocks in regular regimes. Insurance is the most effective form of disaster resilience and in the case of low-income individuals Raynor and Panza (2021) emphasize also the importance of government social security payments.

\subsection{Impact of globalization on insurance sector}

Integration through mergers and acquisitions is also a significant phenomenon of globalization. As of September 1, 2021, there were 13 insurance companies and 20 branches of foreign insurance companies operating in Slovakia. Acquisitions on the Slovak insurance market were mainly reflected in Austrian insurance groups. In 2018, Vienna Insurance Group merged Poist'ovňa Slovenská sporitel'ňa through the insurance company KOOPERATIVA. In 2020 the Austrian group UNIQA Insurance Group completed the acquisition of AXA in the Slovak Republic. In 2020, AEGON Životná poist'ovňa, a branch of the Dutch insurance company AEGON N.V. merged with NN Životná poist'ovňa, which is also part of the Dutch international group NN. From the point of view of insurance owners, the main motivation for acquisitions is to achieve cost savings, but from the point of view of the Slovak insurance market, competition in the market is decreasing, which may cause a distortion of the supply of insurance products. In the Slovak Republic, the market share of foreign companies on the domestic market in non-life insurance is $96.8 \%$, compared to $87.8 \%$ in life insurance. Similar situation is reported also in the Czech Republic, Hungary, Lithuania, Latvia and Estonia. However, in Poland the share of non-life insurance is $60 \%$, compared to $44.5 \%$ in the case of life insurance. In Austria 33.1\% in non-life insurance is reported, compared to 39\% in life insurance; in Germany in both cases insurance reaches over $13 \%$ market share of foreign companies (OECD, 2020). As of June 2021, the largest share $32.4 \%$ of written premiums in 
non-life insurance in the Slovak insurance market is reported in the case of the largest insurance company in the Slovak Republic, Allianz - Slovenská poist'ovňa. This company is a member of the global Allianz SE based in Germany. This insurance company is followed by the insurance companies of the Austrian group VIG KOOPERATIVA and Komunálna poist'ovňa, which together account for almost $29 \%$. KOOPERATIVA poist'ovňa is the leader in life insurance, with less than $27 \%$. This insurance company achieved many awards, such as Superbrands in 2013, 2019, and 2020. In addition, in the years 2016-2019 this company was also awarded with Hermes communicator, which is an award for the quality of communication. With regard to life insurance, the second largest company Allianz poist'ovña is followed by the Dutch NN insurance company with its $11.5 \%$ (see in Table 1). In 2021, NN Slovensko became one of the top 20 most popular brands on the Slovak market as part of a KPMG survey and ranked second in the financial services and health insurance sectors.

Table 1. Insurance companies and branches of foreign insurance companies operating in Slovakia with the largest share of written premiums in life and non-life insurance on the insurance market as of June 2021

\begin{tabular}{|l|r|r|}
\hline & $\begin{array}{r}\text { life } \\
\text { insurance }\end{array}$ & $\begin{array}{r}\text { non-life } \\
\text { insurance }\end{array}$ \\
\hline Allianz - Slovenská poist'ovňa, a. s. & $20,23 \%$ & $32,42 \%$ \\
\hline ČSOB Poist'ovňa, a. s. & $2,67 \%$ & $4,83 \%$ \\
\hline Generali Poist'ovňa, a. s. & $9,91 \%$ & $13,78 \%$ \\
\hline Komunálna poist'ovňa a. s., Vienna Insurance Group & $2,72 \%$ & $5,38 \%$ \\
\hline KOOPERATIVA poist'ovňa, a. s., Vienna Insurance Group & $26,74 \%$ & $23,37 \%$ \\
\hline NN Životná poist'ovňa, a. s. & $11,48 \%$ & $0,00 \%$ \\
\hline UNIQA poist'ovňa, a. s. & $3,43 \%$ & $7,04 \%$ \\
\hline AXA životní pojištovna a. s., pobočka poist'ovne z iného členského štátu &, $88 \%$ & $0,18 \%$ \\
\hline MetLife Europe d. a. c., pobočka poist'ovne z iného členského štátu & $10,54 \%$ & $0,59 \%$ \\
\hline
\end{tabular}

Source: authors' calculations

\subsection{Impact of COVID-19 pandemic on insurance companies in the Slovak Republic}

With regard to the COVID-19 pandemic, The European Insurance and Occupational Pensions Authority is in contact with the European Supervisory Authorities. Concerning this, in March 2020, in their recent statement they emphasized the importance of maintaining a balanced capital position for insurers in dividends and other income, including the variable remuneration component in order to protect their rights. In addition, insurance companies undertake activities to support customers: by raising awareness - through creating websites; targeted impact - through flexibility of the insurance contract or premiums written, requirements for contractual obligations such as submission of paper documentation, renewal of tests, or certificates. As part of the travel insurance, the insurance companies extended the validity of the travel insurance if the client got stuck abroad due to quarantine, they ensured possible repatriations. Each insurance company differs in size as well as in its risk profile, the more important it is to manage capital so that it is able to fulfil contractual promises to customers even in times of pandemic.

Since the beginning of the pandemic, insurance companies in the Slovak Republic pointed to difficult physical contact with the client, the adjustment of opening hours (limited time), which also directly affected the sale of contracts, but the positive thing is that there was no increase in buyouts. There were also restrictions in order to inspect the damage, or the client could submit his own photo documentation of the damage. Reporting of damages was done only by phone, e-mail or via the application. Insurance companies individually assessed the possible consequences of the invalidity of technical and emission controls. With regard to 
this, the importance of online insurance has been confirmed in this situation. In addition to the special measures mentioned above by insurance companies due to the pandemic, there were also particular activities specific to their parent companies.

In 2020, the profit of insurance companies was also higher, the pace of its growths was the fastest from 2016, which was mainly due to savings in claims incurred and the creation of reserves. Net profit increased by $9.8 \%$ to 184 million Euros. All insurance companies in the Slovak Republic ended in positive numbers and approximately half of the insurance companies recorded profit growth.

The impact of the pandemic on non-life insurance premiums written in the Slovak Republic was modest; in 2020, its growth slowed by half to $1.8 \%$ year-on-year. Car insurance $(+4.5 \%)$ and property insurance $(+1.7 \%)$ were growing even slightly faster than last year.

Quarantine measures had a positive effect on claims in car insurance. According to the data of the Ministry of the Interior of the Slovak Republic, there were 14\% less traffic accidents in 2020 than in the previous year. As a result, insurance companies saved $12.4 \%$ of costs and the combined ratio (net) fell to $94.8 \%$, although it is still the worst value among the non-life insurance sector. As car insurance accounts for $60 \%$ of non-life insurance, even a small change in the combined ratio has a visible impact on finances of this sector.

The economic result in non-life insurance (technical result) increased by $54 \%$ year-onyear to 86 million Euros. In life insurance there was a more significant decrease in premiums written in 2020 compared to previous years, in conventional life insurance the year-on-year decrease deepened to $-11.6 \%$. Investment life insurance decreased to $-8.5 \%$ as well. In both cases this decline was caused mainly by a decrease in new production.

The financial result of the life insurance (excluding investment life insurance) decreased by $10 \%$ year-on-year to 90 million Euros. Other products affected by the pandemic include also credit insurance and travel agency insurance against insolvency, in which no fundamental changes have taken place in the Slovak Republic. Insured events are still in low numbers and movements in financial indicators are influenced more by individual claims and base effects. The risk of losses from these sectors is carried over to the year 2021, especially in the event of the termination of government measures to support the affected sectors.

Even during the pandemic, Slovak insurance companies remained sufficiently resilient to adverse shocks. At the end of 2020, insurance companies met the Solvency Capital Requirement (SCR) at $192 \%$, which is comparable to 2019 . However, the quality of capital deteriorated, with the share of the volatile component of expected earnings from future premiums (EPIFP), which was rising from the level of $49 \%$ to $58 \%$ in 2020 . Return on equity (ROE) increased despite an increase in own funds. The increase was 0.5 p. b. to $13.78 \%$. On the positive side, not only the profit but also the volume of own funds has increased, as it has increased the value of Return on Equity (ROE) in recent years with a decrease in own funds (NBS, 2021).

\section{Methods}

Insurance companies are among the major players in the Slovak financial market. In 2019, they managed $4.3 \%$ of the total volume of assets of the financial sector, by 2020 this share had decreased to $4 \%$. Assessing the financial management of insurance companies is one of the important components of their financial management. The aim of our paper is to identify and quantify the impact of the COVID 19 pandemic and related measures and consequences on the financial situation of insurance companies. The period under review is the accounting periods 2016-2020. Data on financial results are obtained from the annual reports of the companies from the Statements of selected data, which the companies publish in the Register of Financial Statements. The sample consists of a total of 12 insurance companies based in the Slovak Republic, which operated on the market in all years examined. Their share in 
aggregate gross written premiums averaged $85 \%$ during the period under review (see Table 2), so we consider this data set to be representative.

Table 2. Market share of researched insurance companies on aggregate gross written premiums (GWP) in Slovak insurance market

\begin{tabular}{|l|r|r|r|r|r|r|}
\hline Insurance company & 2016 & 2017 & 2018 & 2019 & 2020 & Average \\
\hline Allianz & $24.71 \%$ & $23.82 \%$ & $25.01 \%$ & $25.22 \%$ & $26.10 \%$ & $24.97 \%$ \\
\hline BNP Paribas & $1.08 \%$ & $1.01 \%$ & $1.18 \%$ & $1.27 \%$ & $1.33 \%$ & $1.18 \%$ \\
\hline ČSOB & $3.82 \%$ & $3.60 \%$ & $3.82 \%$ & $3.56 \%$ & $3.60 \%$ & $3.68 \%$ \\
\hline Generali & $9.35 \%$ & $9.38 \%$ & $9.79 \%$ & $10.19 \%$ & $10.97 \%$ & $9.93 \%$ \\
\hline KOMUNÁLNA & $8.42 \%$ & $8.14 \%$ & $7.39 \%$ & $7.32 \%$ & $4.84 \%$ & $7.22 \%$ \\
\hline KOOPERATIVA & $20.61 \%$ & $19.53 \%$ & $24.64 \%$ & $24.76 \%$ & $24.43 \%$ & $22.80 \%$ \\
\hline NN & $3.33 \%$ & $3.11 \%$ & $3.00 \%$ & $2.95 \%$ & $5.26 \%$ & $3.53 \%$ \\
\hline NOVIS & $0.57 \%$ & $1.00 \%$ & $1.57 \%$ & $1.65 \%$ & $1.91 \%$ & $1.34 \%$ \\
\hline Poštová poist'ovňa & $0.59 \%$ & $0.59 \%$ & $0.63 \%$ & $0.66 \%$ & $0.70 \%$ & $0.63 \%$ \\
\hline Union & $2.20 \%$ & $2.21 \%$ & $2.28 \%$ & $2.51 \%$ & $2.41 \%$ & $2.32 \%$ \\
\hline UNIQA & $5.08 \%$ & $5.05 \%$ & $5.16 \%$ & $4.93 \%$ & $5.12 \%$ & $5.07 \%$ \\
\hline Wüstenrot & $2.62 \%$ & $2.38 \%$ & $2.24 \%$ & $2.15 \%$ & $2.05 \%$ & $2.29 \%$ \\
\hline Others & $17.60 \%$ & $20.17 \%$ & $13.30 \%$ & $12.83 \%$ & $11.28 \%$ & $15.04 \%$ \\
\hline GWP (EUR '000) & $2,235,203$ & $2,399,920$ & $2,515,071$ & $2,561,110$ & $2,500,068$ & $2,442,274$ \\
\hline
\end{tabular}

Source: authors' calculations

We examine the financial situation of insurance companies using selected indicators of financial analysis, which are also used by Standard \& Poor's in the rating of insurance companies. When evaluating the significance of year-on-year changes in the value of the examined indicators of financial performance of insurance companies, we use the TwoRelated-Sample test, specifically the Wilcoxon signed-rank test. We formulate 1-tailed hypotheses $\left(\mathrm{H}_{0}: \mu_{0}=\mu_{1}, \mathrm{H}_{1}: \mu_{0}<\mu_{1}\right.$ resp. $\left.\mathrm{H}_{1}: \mu_{0}>\mu_{1}\right)$ and verify them at the significance level $\alpha=0.05$.

\section{Results and Discussions}

The results of our research are presented in Table 3, which contains the Z-score of Wilcoxon statistic and the p-value of this test (1-tailed Sig.). If the Z-score is based on negative ranks, it means that in most cases there was an increase in the value of the indicator between the observed periods and vice versa, if the Z-score is based on positive ranks, most indicators recorded a decrease between periods. In Table 3 we present the value of the effect size ( $r$ ), which informs about an objective and usually standardized measure of the magnitude of an observed effect between variables. "Annual mean" informs about the average annual value of the indicator, which we calculated by a simple arithmetic average from the data of individual examined insurance companies, and "change in mean" quantifies its change compared to the previous accounting period.

Table 3. Wilcoxon Signed Ranks Test, Mean Statistics

\begin{tabular}{|c|c|c|c|c|c|c|}
\hline & Statistics & $2016-2015$ & $2017-2016$ & $2018-2017$ & 2019-2018 & 2020-2019 \\
\hline \multirow{5}{*}{ 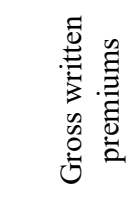 } & $\mathrm{Z}$ & $-2.510^{b}$ & $-2.589^{b}$ & $-2.353^{b}$ & $-1.647^{\mathrm{b}}$ & $-.235^{\mathrm{b}}$ \\
\hline & Sig. (1-tailed) & .005 & .004 & .008 & .053 & .435 \\
\hline & Effect size & -.512 & -.528 & -.480 & -.336 & -.048 \\
\hline & Annual mean $(€)$ & $153,479,725$ & $159,645,860$ & $181,719,281$ & $186,047,708$ & $184,833,841$ \\
\hline & Change of mean & .060 & .040 & .138 & .024 & -.007 \\
\hline
\end{tabular}




\begin{tabular}{|c|c|c|c|c|c|c|}
\hline \multirow{5}{*}{ 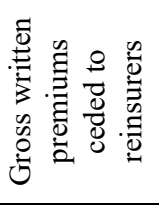 } & $\mathrm{Z}$ & $-.941^{b}$ & $-.235^{\mathrm{b}}$ & $-.706^{\mathrm{b}}$ & $-.235^{\mathrm{c}}$ & $-.941^{b}$ \\
\hline & Sig. (1-tailed) & .187 & .429 & .259 & .417 & .187 \\
\hline & Effect size & -.192 & -.048 & -.144 & -.048 & -.192 \\
\hline & Annual mean $(€)$ & $25,697,167$ & $26,029,250$ & $26,281,917$ & $26,587,500$ & $29,176,450$ \\
\hline & Change of mean & -.018 & .013 & .010 & .012 & 097 \\
\hline \multirow{5}{*}{ 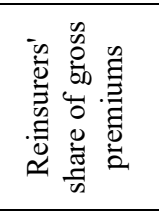 } & $Z$ & $-1.412^{b}$ & $-1.490^{\mathrm{b}}$ & $-1.804^{b}$ & $-.392^{b}$ & $-1.177^{\mathrm{c}}$ \\
\hline & Sig. (1-tailed) & .091 & .078 & .039 & .372 & .137 \\
\hline & Effect size & -.288 & -.304 & -.368 & -.080 & -.240 \\
\hline & Annual mean & .139 & .133 & .124 & .135 & .178 \\
\hline & Change of mean & -.215 & -.046 & -.067 & .088 & .318 \\
\hline \multirow{5}{*}{ 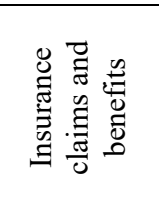 } & $Z$ & $-1.490^{b}$ & $-1.569^{b}$ & $-1.569^{\mathrm{b}}$ & $-1.412^{b}$ & $-.941^{\mathrm{c}}$ \\
\hline & Sig. (1-tailed) & .071 & .059 & .059 & .084 & .193 \\
\hline & Effect size & -.304 & -.320 & -.320 & -.288 & -.192 \\
\hline & Annual mean $(€)$ & $95,497,333$ & $97,721,212$ & $111,412,700$ & $118,442,929$ & $109,153,085$ \\
\hline & Change of mean & .073 & .023 & .140 & .063 & -.078 \\
\hline \multirow{5}{*}{ 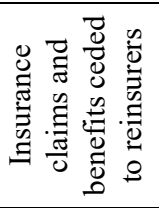 } & Z & $-1.423^{b}$ & $-1.804^{c}$ & $-.314^{b}$ & $-.784^{b}$ & $-.235^{\mathrm{c}}$ \\
\hline & Sig. (1-tailed) & .087 & .037 & .399 & .236 & .423 \\
\hline & Effect size & -.303 & -.368 & -.064 & -.160 & -.048 \\
\hline & Annual mean $(€)$ & $14,496,417$ & $10,814,116$ & $11,231,892$ & $10,919,123$ & $13,015,472$ \\
\hline & Change of mean & .204 & -.254 & .039 & -.028 & .192 \\
\hline \multirow{5}{*}{ 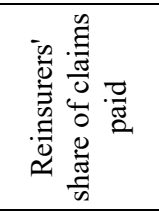 } & Z & $-.889^{\mathrm{b}}$ & $-2.118^{c}$ & $-.471^{b}$ & $-1.412^{c}$ & $-1.412^{b}$ \\
\hline & \begin{tabular}{|l} 
Sig. (1-tailed) \\
\end{tabular} & .208 & .016 & .344 & .086 & .088 \\
\hline & Effect size & -.190 & -.432 & -.096 & -.288 & -.288 \\
\hline & Annual mean & .040 & .081 & .089 & .071 & .087 \\
\hline & Change of mean & -.558 & 1.040 & .102 & -.202 & .229 \\
\hline \multirow{5}{*}{ 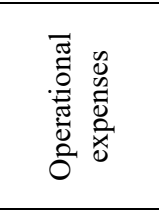 } & Z & $-.078^{b}$ & $-1.412^{\mathrm{c}}$ & $-.941^{\mathrm{c}}$ & $-1.647^{c}$ & $-1.804^{c}$ \\
\hline & Sig. (1-tailed) & .476 & .088 & .195 & .057 & .038 \\
\hline & Effect size & -.016 & -.288 & -.192 & -.336 & -.368 \\
\hline & Annual mean $(€)$ & $44,141,984$ & $45,416,931$ & $46,980,086$ & $54,046,953$ & $58,168,516$ \\
\hline & Change of mean & -.181 & .029 & .034 & .150 & .076 \\
\hline \multirow{5}{*}{ 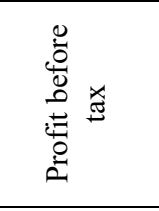 } & $Z$ & $-1.726^{b}$ & $-.784^{c}$ & $-.078^{\mathrm{c}}$ & $-1.177^{b}$ & $-1.334^{b}$ \\
\hline & Sig. (1-tailed) & .047 & .231 & .490 & .137 & .106 \\
\hline & Effect size & -.352 & -.160 & -.016 & -.240 & -.272 \\
\hline & Annual mean $(€)$ & $18,937,703$ & $17,172,923$ & $17,018,892$ & $18,274,447$ & $21,154,167$ \\
\hline & Change of mean & .399 & -.093 & -.009 & .074 & .158 \\
\hline \multirow{5}{*}{ 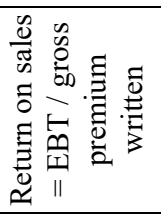 } & $Z$ & $-1.098^{b}$ & $-.784^{c}$ & $-1.726^{c}$ & $-.863^{b}$ & $-.314^{c}$ \\
\hline & \begin{tabular}{|l|} 
Sig. (1-tailed) \\
\end{tabular} & .151 & .235 & .047 & .211 & .388 \\
\hline & Effect size & -.224 & -.160 & -.352 & -.176 & -.064 \\
\hline & Annual mean & .159 & .113 & .096 & .106 & .093 \\
\hline & Change of mean & .470 & -.292 & -.151 & .102 & -.122 \\
\hline \multirow{5}{*}{ 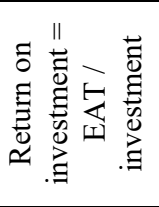 } & $Z$ & $-.157^{b}$ & $-.706^{b}$ & $-.628^{b}$ & $-.549^{\mathrm{b}}$ & $-.392^{b}$ \\
\hline & Sig. (1-tailed) & .458 & .261 & .288 & .315 & .370 \\
\hline & Effect size & -.032 & -.144 & -.128 & -.112 & -.080 \\
\hline & Annual mean & .097 & .054 & .048 & .041 & .030 \\
\hline & Change of mean & .707 & -.444 & -.114 & -.144 & -.265 \\
\hline \multirow{5}{*}{ 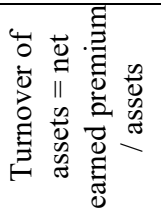 } & $Z$ & $-.471^{b}$ & $-2.118^{b}$ & $-1.490^{b}$ & $-2.118^{c}$ & $-2.040^{c}$ \\
\hline & Sig. (1-tailed) & .342 & .016 & .080 & .017 & .022 \\
\hline & Effect size & -.096 & -.432 & -.304 & -.432 & -.416 \\
\hline & Annual mean & .304 & .317 & .349 & .336 & .308 \\
\hline & Change of mean & .020 & .043 & .102 & -.037 & -.084 \\
\hline
\end{tabular}




\begin{tabular}{|c|c|c|c|c|c|c|}
\hline \multirow{5}{*}{ 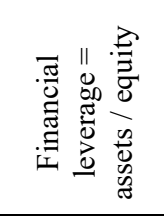 } & $z$ & $-1.177^{b}$ & $-2.432^{b}$ & $-1.647^{b}$ & $-.549^{c}$ & $-.941^{\mathrm{c}}$ \\
\hline & Sig. (1-tailed) & .131 & .006 & .054 & .309 & .189 \\
\hline & Effect size & -.240 & -.496 & -.336 & -.112 & -.192 \\
\hline & Annual mean & 4.996 & 5.650 & 5.952 & 5.063 & 4.865 \\
\hline & Change of mean & .058 & .131 & .053 & -.149 & -.039 \\
\hline \multirow{5}{*}{ 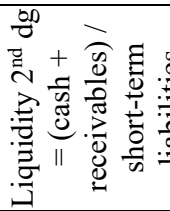 } & $Z$ & $-1.098^{b}$ & $-1.490^{b}$ & $-1.412^{b}$ & $-.784^{\mathrm{c}}$ & $-1.961^{\mathrm{c}}$ \\
\hline & Sig. (1-tailed) & .148 & .073 & .083 & .240 & .026 \\
\hline & Effect size & -.224 & -.304 & -.288 & -.160 & -.400 \\
\hline & Annual mean & 1.004 & 1.123 & 1.726 & 1.673 & 1.154 \\
\hline & Change of mean & -.014 & .118 & .537 & -.031 & -.310 \\
\hline \multirow{5}{*}{ 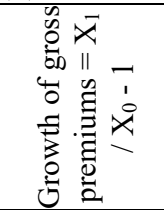 } & $Z$ & $-.078^{b}$ & $-.314^{b}$ & $-1.569^{c}$ & $-2.197^{b}$ & $-.941^{b}$ \\
\hline & \begin{tabular}{|l|} 
Sig. (1-tailed) \\
\end{tabular} & .490 & .402 & .062 & .013 & .197 \\
\hline & Effect size & -.016 & -.064 & -.320 & -.448 & -.192 \\
\hline & Annual mean & .137 & .105 & .142 & .031 & .039 \\
\hline & Change of mean & -.510 & -.235 & .355 & -.778 & .224 \\
\hline \multirow{5}{*}{ 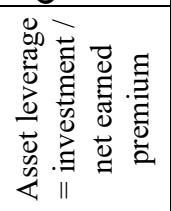 } & $Z$ & $-1.255^{\mathrm{b}}$ & $-1.726^{b}$ & $-1.412^{\mathrm{b}}$ & $-1.490^{c}$ & $-2.040^{c}$ \\
\hline & Sig. (1-tailed) & .116 & .047 & .090 & .079 & .023 \\
\hline & Effect size & -.256 & -.352 & -.288 & -.304 & -.416 \\
\hline & Annual mean & 2.727 & 2.622 & 2.601 & 3.022 & 5.282 \\
\hline & Change of mean & -.062 & -.038 & -.008 & .162 & .748 \\
\hline \multirow{5}{*}{ 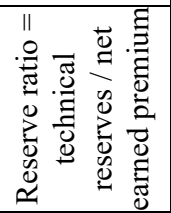 } & $Z$ & $-.549^{b}$ & $-.078^{c}$ & $-1.412^{\mathrm{b}}$ & $-1.647^{c}$ & $-2.197^{c}$ \\
\hline & \begin{tabular}{|l|} 
Sig. (1-tailed) \\
\end{tabular} & .314 & .486 & .086 & .054 & .014 \\
\hline & Effect size & -.112 & -.016 & -.288 & -.336 & -.448 \\
\hline & Annual mean & 2.264 & 2.269 & 2.200 & 2.355 & 3.107 \\
\hline & Change of mean & -.015 & .002 & -.030 & .070 & .319 \\
\hline \multirow{5}{*}{ 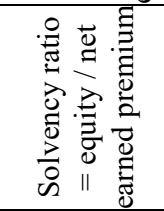 } & $Z$ & $-2.118^{\mathrm{b}}$ & $-2.432^{b}$ & $-2.667^{b}$ & $-1.098^{c}$ & $-1.883^{\mathrm{c}}$ \\
\hline & Sig. (1-tailed) & .017 & .006 & .003 & .150 & .031 \\
\hline & Effect size & -.432 & -.519 & -.569 & -.224 & -.384 \\
\hline & Annual mean & .794 & .714 & .612 & .713 & 1.155 \\
\hline & Change of mean & -.107 & -.101 & -.143 & .166 & .619 \\
\hline \multirow{5}{*}{ 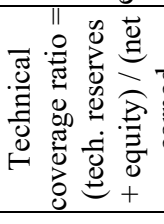 } & $Z$ & $-1.490^{\mathrm{b}}$ & $-1.883^{b}$ & $-2.353^{\mathrm{b}}$ & $-1.961^{\mathrm{c}}$ & $-2.197^{\mathrm{c}}$ \\
\hline & \begin{tabular}{|l|} 
Sig. (1-tailed) \\
\end{tabular} & .078 & .033 & .009 & .029 & .016 \\
\hline & Effect size & -.304 & -.384 & -.480 & -.400 & -.448 \\
\hline & Annual mean & 3.058 & 2.982 & 2.812 & 3.068 & 4.262 \\
\hline & Change of mean & -.041 & -.025 & -.057 & .091 & .389 \\
\hline \multirow{5}{*}{ 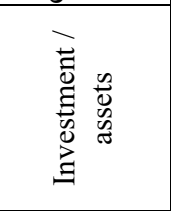 } & $Z$ & $-1.177^{b}$ & $-.078^{c}$ & $-.314^{b}$ & $-1.098^{c}$ & $-.078^{b}$ \\
\hline & \begin{tabular}{|l|} 
Sig. (1-tailed) \\
\end{tabular} & .133 & .486 & .392 & .148 & .480 \\
\hline & Effect size & -.240 & -.016 & -.064 & -.224 & -.016 \\
\hline & Annual mean & .711 & .711 & .760 & .760 & .749 \\
\hline & Change of mean & -.059 & -.001 & .070 & .000 & -.014 \\
\hline \multirow{5}{*}{ 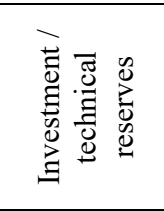 } & Z & $-1.726^{b}$ & $-2.432^{b}$ & $-.706^{b}$ & $-1.490^{c}$ & $-.471^{b}$ \\
\hline & \begin{tabular}{|l|} 
Sig. (1-tailed) \\
\end{tabular} & .046 & .007 & .256 & .078 & .336 \\
\hline & Effect size & -.352 & -.496 & -.144 & -.304 & -.096 \\
\hline & Annual mean & 1.259 & 1.187 & 1.298 & 1.323 & 1.286 \\
\hline & Change of mean & -.069 & -.057 & .093 & .019 & -.028 \\
\hline \multirow{5}{*}{ 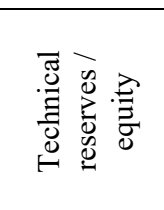 } & Z & $-.314^{b}$ & $-2.353^{b}$ & $-1.804^{b}$ & $-.784^{c}$ & $-.784^{c}$ \\
\hline & \begin{tabular}{|l|} 
Sig. (1-tailed) \\
\end{tabular} & .389 & .008 & .038 & .229 & .229 \\
\hline & Effect size & -.064 & -.480 & -.368 & -.160 & -.160 \\
\hline & \begin{tabular}{|l|} 
Annual mean \\
\end{tabular} & 3.290 & 3.851 & 4.036 & 3.214 & 3.061 \\
\hline & Change of mean & .071 & .170 & .048 & -.204 & -.048 \\
\hline
\end{tabular}




\begin{tabular}{|c|c|c|c|c|c|c|}
\hline \multirow{5}{*}{ 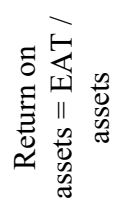 } & $\mathrm{Z}$ & $-.549^{b}$ & $-1.177^{\mathrm{c}}$ & $-.863^{c}$ & $.000^{\mathrm{a}}$ & $-.314^{c}$ \\
\hline & Sig. (1-tailed) & .305 & .135 & .214 & .513 & .395 \\
\hline & Effect size & -.112 & -.240 & -.176 & .000 & -.064 \\
\hline & Annual mean & .037 & .027 & .023 & .024 & .020 \\
\hline & Change of mean & .156 & -.286 & -.132 & .016 & -.168 \\
\hline \multirow{5}{*}{ 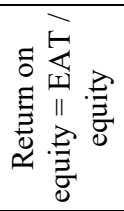 } & $Z$ & $-.863^{\mathrm{b}}$ & $-.157^{\mathrm{b}}$ & $-.392^{b}$ & $-.628^{\mathrm{c}}$ & $-.706^{\mathrm{c}}$ \\
\hline & Sig. (1-tailed) & .205 & .450 & .361 & .286 & .263 \\
\hline & Effect size & -.176 & -.032 & -.080 & -.128 & -.144 \\
\hline & Annual mean & .137 & .118 & .110 & .099 & .091 \\
\hline & Change of mean & .161 & -.139 & -.069 & -.094 & -.083 \\
\hline
\end{tabular}

Note: aThe sum of negative ranks equals the sum of positive ranks, bBased on negative ranks, cBased on positive ranks.

Source: authors' calculations

The basic indicator by which insurance companies measure their financial performance is the volume of gross written premiums. The aggregate statistics of the Slovak insurance market show a year-on-year decrease in this indicator between 2019 and 2020. Based on the information that the Z-score is based on negative rank, we can state that most of the insurance companies recorded an increase in gross premiums written. Out of the total number of 12 surveyed insurance companies, between 2019 and 2020, 7 insurance companies recorded an increase in the volume of written premiums, in the total amount of $84.41 \mathrm{mil}$. EUR and 5 insurance companies recorded a decrease in written premiums in the total amount of 98.98 mil. EUR. The largest increase in the average amount of premiums $(13.8 \%)$ was between 2017 and 2018, in the following period it was only $2.4 \%$ and between 2019 and 2020 there was a decrease in the average value of written premiums by $0.7 \%$. In 2020 , the surveyed insurance companies collected a total by 14.57 mil. EUR lower gross written premiums. Only changes during 2016, 2017 and 2018 can be considered statistically significant, when the significance of value does not exceed 0.05. The changes in 2019 and 2020 cannot be considered statistically significant. The results point to a decrease in gross premiums written since 2018 and this development was not caused solely by the COVID 19 pandemic. Based on the effect size, we identify a year-on-year decline since 2017. Between 2019 and 2020, there was also an increase in the volume of written premiums ceded to reinsurers and the share of reinsurers in written premiums also increased.

The cost of insurance benefits is closely related to the occurrence of insurance risk. However, their total amount is also affected by the structure of insurance products in the insurance company's portfolio. Between 2019 and 2020, there was a decrease (-7.8\%) in the average value of insurance claims and benefits, as well as an increase in average insurance claims and benefits ceded to reinsurers (19.2\%) and reinsurers' share of claims paid (22.9\%). These changes are related to the increase in risk due to the global pandemic, but they cannot be considered statistically significant. We found a significant year-on-year change between 2019 and 2020 in terms of personnel costs, which began to increase year-on-year as early as 2019. According to the effect size, these changes have a medium intensity.

We further identified statistically significant changes between 2019 and 2020 in the indicator Turnover of assets, which decreased by $8.4 \%$ year-on-year, in liquidity of the 2 nd degree $(-3.1 \%)$, asset leverage $(74.8 \%)$, solvency ratio $(61.9 \%)$ and technical coverage ratio $(38.9 \%)$.

Turnover assets inform about the ability of the insurance company to use its assets to generate income. The increase in this indicator is positive. We find that this ability of insurance companies decreased significantly in 2019 and 2020, which was caused by an increase in the volume of insurance companies' assets by an average of $5.7 \%$ and a decrease in net earned premiums by an average of $1.4 \%$. Assets were mostly affected by a decline in 
insurance companies' holdings in other companies (-56.7\%), and an increase in the volume of financial instruments available for sale (130.4\%) and intangible assets (34.5\%). Likewise, the development of liquidity in insurance companies is not favorable. This development was caused by a significant increase in short-term liabilities of insurance companies in 2019 $(20 \%)$ and $2020(17.8 \%)$.

On the contrary, a positive development occurred in the asset leverage indicator, which is also used by Standard \& Poor's in the assessment of insurance companies, and which increased year-on-year mainly due to significant investment growth, by $8.6 \%$ on average in 2019 and $6.5 \%$ in 2020 .

Solvency ratio is the ratio of equity to net earned premium. The recommended interval by Standard \& Poor's is from $30 \%$ to $50 \%$. As a result of a significant increase in the equity value (2019: 18.4\%; 2020: 19.3\%) and a gradual decline in the volume of net earned premium since 2018 , the solvency ratio in insurance companies domiciled in the Slovak Republic reached $69.6 \%$ in 2020 . In the surveyed insurance companies, the solvency ratio averaged $115.5 \%$, mainly due to its extreme value in the NOVIS insurance company (588\%). This was caused by the fact that NOVIS ceded up to $87 \%$ of its earned premiums to its reinsurance company in 2020.

Statistically significant changes in the technical coverage ratio are identified in 2016, 2017 and 2019 and 2020. In 2019 and 2020, its value was affected by the growth of adjusted technical provisions (on average by $2.6 \%$ ). The results of our research for the years 20162020 were affected by the extreme increase in adjusted technical provisions in the NOVIS insurance company (on average $77 \%$ per year). The recommended technical coverage ratio by Standard \& Poor's is $150 \%$. Insurance companies based in the Slovak Republic report its value for the studied period on average 336\%, insurance companies included in our research average $324 \%$. The results of the analysis of the development of other examined financial indicators are presented in Table 3.

\section{Conclusion}

Financial management of insurance companies is an integral part of the process of achieving their business success. Insurance companies are among the major financial market players in the Slovak Republic. Their management was partly affected by the COVID pandemic. However, as we can see from the results of our analysis, the ongoing pandemic did not ruin these insurance companies, and at the sometime, they managed to adapt to the situation. Although the reduction in the volume of written premiums also reduced their liquidity, they transferred a large part of the insurance risks to their reinsurance partners and created sufficient technical reserves that could be used to cover the cost of insurance claims. Despite the increase in operating costs, which was partly related to the need for insurance companies to ensure increased demands for disinfection, workplace hygiene and purchase information technology equipment, insurance companies managed to achieve a net profit increase of $10.5 \%$ between the years 2019 and 2020 .

\section{Acknowledgements}

This paper has been supported by the Scientific Grant Agency of Slovak Republic under project VEGA No. 1/0579/21 „Research on Determinants and Paradigms of Financial Management in the context of the COVID-19 Pandemic". The authors would like to express their gratitude to the Scientific Grant Agency of The Ministry of Education, Science, Research and Sport of the Slovak Republic for financial support of this research and publication. 


\section{References}

1. Ecer, F. \& Pamucar, D. (2021). MARCOS technique under intuitionistic fuzzy environment for determining the COVID-19 pandemic performance of insurance companies in terms of healthcare services. Applied Soft Computing, 104, Article 107199.

2. Eling, M., \& Jia, R. (2019). Efficiency and profitability in the global insurance industry. Pacific-Basin Finance Journal, 57, Article 101190.

3. Gaies, B., Goutte, S., \& Guesmi, K. (2020). Does financial globalization still spur growth in emerging and developing countries? Considering exchange rates. Research in International Business and Finance, 52, Article 101113.

4. Gu, H., \& Wang, C. (2020). Impacts of the COVID-19 pandemic on vegetable production and countermeasures from an agricultural insurance perspective. Journal of Integrative Agriculture, 19(12), 2866-2876.

5. Huang, Y.L., \& Shen, C.H. (2021). From revenue to safety: Rating agencies have changed their concerns after the crisis. Journal of International Financial Markets, Institutions and Money, 73, Article 101363.

6. Leong, S.H., Pellegrini, C.B., \& Urga, G. (2020). The contribution of shadow insurance to systemic risk. Journal of Financial Stability, 51, Article 100778.

7. Nasreen, S., Mahalik, M. K., Shahbaz, M., \& Abbas, Q. (2020). How Do Financial Globalization, Institutions and Economic Growth Impact Financial Sector Development in European Countries? Research in International Business and Finance, 54, Article 101247.

8. NBS. (2021, May). Správa o finančnej stabilite. https://www.nbs.sk/_img/Documents/ZAKLNBS/PUBLIK/SFS/protected/SFS_052021 .pdf

9. NBS. (2020). Správa o stave a vývoji finančného trhu. https://www.nbs.sk/_img/Documents/_Dohlad/Makropolitika/Sprava_o_stave_a_vyvoj i_FT_za_1.polrok_2020.pdf

10. Olasehinde-Williams, G., \& Balcilar, M. (2020). Examining the Effect of Globalization on Insurance Activities in Large Emerging Market Economies. Research in International Business and Finance, 53, Article 101228.

11. OECD. (2020). Insurance Statistics 2020. https://read.oecd-ilibrary.org/finance-andinvestment/oecd-insurance-statistics-2020_adfe5566-en\#page38

12. Raynor, K. \& Panza, L. (2021). Tracking the impact of COVID-19 in Victoria, Australia: Shocks, vulnerability and insurances among residents of share houses. Cities, 117, Article 103332.

13. Register of Financial Statements (2021). https://www.registeruz.sk/cruzpublic/domain/accountingentity/simplesearch

14. Ulucak, Z.S. Ilkay, S.C., Ozcan, B., \& Gedıkl1, A. (2020). Financial globalization and environmental degradation nexus: Evidence from emerging economies. Resources Policy, 67, Article 101698.

15. Vera-Valdés, J. E. (2021). The persistence of financial volatility after COVID-19. Finance Research Letters, Article 102056. 